\title{
Understanding allergic asthma from allergen inhalation tests
}

\author{
Donald W Cockcroft MD FRCPC ${ }^{1}$, Fredrick E Hargreave MD FRCPC ${ }^{2}$, Paul M O'Byrne MB CHB FRCPC 2 , \\ Louis-Philippe Boulet MD FRCPC ${ }^{3}$
}

\begin{abstract}
DW Cockcroft, FE Hargreave, PM O'Byrne, LP Boulet. Understanding allergic asthma from allergen inhalation tests. Can Respir J 2007;14(7):414-418.
\end{abstract}

The allergen challenge has evolved, in less than 150 years, from a crude tool used to document the etiology of allergen-induced disease to a well-controlled tool used today to investigate the pathophysiology and pharmacotherapy of asthma. Highlights of the authors' involvement with the allergen challenge include confirmation of the immunoglobulin E-dependence of the late asthmatic response, importance of (nonallergic) airway hyper-responsiveness as a determinant of the airway response to allergen, identification of allergeninduced increase in airway hyper-responsiveness, documentation of beta ${ }_{2}$-agonist-induced increase in airway response to allergen (including eosinophilic inflammation), advances in understanding the pathophysiology and kinetics of allergen-induced airway responses, and development of a muticentre clinical trial group devoted to using the allergen challenge for investigating promising new therapeutic strategies for asthma.

Key Words: Airway responsiveness; Allergen challenge; Asthma; Eosinophils

\section{Comprendre l'asthme allergique à partir des tests d'inhalation des allergènes}

Les tests de provocation allergénique ont évolué en moins de 150 ans, passant d'outils sans finesse utilisés pour documenter l'étiologie de maladies provoquées par les allergènes, à des instruments bien contrôlés, désormais utilisés pour étudier la physiopathologie et la pharmacothérapie de l'asthme. Les points saillants des travaux réalisés par les auteurs sur les tests de provocation allergénique incluent : la confirmation de la dépendance de la réponse asthmatique tardive à l'immunoglobuline E, l'importance de l'hyperréactivité bronchique (non allergique) à titre de facteur déterminant dans la réponse des voies respiratoires aux allergènes, l'identification de l'augmentation de l'hyperréactivité bronchique induite par les allergènes, la documentation de l'exacerbation de la réactivité des voies respiratoires aux allergènes induite par les bêta ${ }_{2}$-agonistes (y compris l'inflammation à éosinophiles), les avancées dans la compréhension de la physiopathologie et de la cinétique des réactions respiratoires induites allergéniques et la mise sur pied d'un groupe pour la conduite d'essais cliniques multicentriques consacrés à l'utilisation des tests de provocation allergéniques dans la recherche sur de nouvelles stratégies thérapeutiques prometteuses pour l'asthme.

\begin{abstract}
$\Delta$ irway challenge with allergen was first used in the latter Ahalf of the 19th century as a means to document the etiology (at that time controversial) of what we now recognize as allergic rhinitis and allergic asthma (1). Allergen challenge has evolved, particularly over the past 40 years, to a carefully controlled procedure, which has provided invaluable insight into the mechanisms and pathogenesis of asthma, and also evolved as a tool to investigate both new and old pharmacological agents. The present report reviews the history of the allergen challenge and summarizes the important advances that have been made using this model.
\end{abstract}

\section{HISTORY}

It is less than 200 years since Bostock (2) provided the first good clinical description of what we now recognize as seasonal allergic rhinitis and asthma. This condition, reported to be quite uncommon at that time, was known as summer catarrh or rose catarrh, roses likely being a more visible but coincidental marker of the grass pollen season. The terms hay fever and hay asthma appeared in the English language circa 1828 (3) because of the common relationship of these symptoms to the haying (and grass) season. Controversy existed as to the cause of the symptoms; some experts attributed the symptoms to emanations from the hay, while others felt that this was coincidence and the true cause was related to a combination of heat, sunshine, humidity and exercise (3). In 1873, Charles Blackley (1) published his classic monograph, documenting pollen - grass pollen in particular - as the cause of these seasonal symptoms. Blackley does refer to some published cases of nasal symptoms induced by the application of whole pollen grains; however, Blackley's treatise is widely regarded as the first substantial publication using allergen challenge. Subsequently, numerous other allergens (pollen, mammals, molds, arthropods, etc) have been identified and allergic disease has become strikingly more prevalent, being described as a postindustrial revolution epidemic (4).

In the early part of the 20th century, before approximately 50 years ago, there are scattered published reports regarding allergen challenges (5-14). Challenges were generally performed with nebulized solutions of allergen. The challenges focused primarily on the immediate or so-called early asthmatic response (EAR). The end points were, by today's standards, very insensitive, and included signs and symptoms of asthma, as well as insensitive measures of lung function such

${ }^{1}$ University of Saskatchewan, Saskatoon, Saskatchewan; ${ }^{2}$ McMaster University, Hamilton, Ontario; ${ }^{3}$ Université de Laval, Quebec City, Quebec

Correspondence: Dr Donald W Cockcroft, Royal University Hospital, Division of Respirology, Critical Care and Sleep Medicine,

103 Hospital Drive, Ellis Hall, Room 551, Saskatoon, Saskatchewan S7N 0W8. Telephone 306-966-8274 ext 2, fax 306-966-8694,

e-mail don.cockcroft@usask.ca 
as maximum breathing capacity and vital capacity. Challenges were used both as a diagnostic tool (14) and as a means of allergen hyposensitization (10).

The late asthmatic response (LAR), which occurs $3 \mathrm{~h}$ to $8 \mathrm{~h}$ or more after allergen exposure, is now recognized as clinically more important than the EAR (15). There is an excellent clinical description of an allergen-induced LAR following accidental high-dose grass pollen exposure in Blackley's monograph (1). The next reports of LARs did not occur until the early 1950s. In Herxheimer's experiments $(8-10,13)$, primarily involving hyposensitization, he noted that many of his patients complained of late symptoms, but with one exception, objective data were not obtained. Herxheimer surmised that most of these represented continuation of the EAR, often with interval improvement produced by the bronchodilator administered for its treatment. He did, however, record isolated symptomatic LARs in a significant number of patients, more common with house dust than with pollen (13).

In the 1940s in France, Tiffeneau and Pinelli (16) used new technology to measure (for the first time) expiratory flow rates. They described what in English has become known as the forced expiratory volume in $1 \mathrm{~s}(17)$, and by the late 1950s, this had become the standard lung function test used to assess airflow obstruction and to monitor bronchoprovocation, including allergen challenges (18). Using his new technology, the biphasic nature of the airway response to allergen (EAR, spontaneous resolution and LAR) was recognized (19). The allergen challenge model was used, particularly in the Netherlands (20-23) and in the United Kingdom (24-27), to document effectiveness of asthma drugs. The immunopathogenesis of the LAR was hotly debated. Professor Pepys (25) in the United Kingdom, who was researching both asthma and allergic alveolitis, as well as allergic bronchopulmonary aspergillosis (which may combine some features of both asthma and alveolitis), strongly suggested that the LAR was a type III or immune complex hypersensitivity response, whereas the Dutch argued that evidence favoured a type I or immunoglobulin E (IgE)-mediated ( $\mathrm{IgE}$ being identified in 1967 [28]) response (23). Dr Hargreave's training and experience in professor Pepys' laboratory led to further studies in this area. These include several first-time important observations; highlights over the past 35 years are reviewed below.

\section{EARLY STUDIES}

\section{IgE-dependence of the LAR}

The first allergen challenge study published from the Hamilton, Ontario, group is a study documenting ragweed pollen as a common cause of late responses in both the airway and the skin (29). The available immunological data in these subjects failed to support type III hypersensitivity while favouring the likelihood of the IgE-dependence of the LAR. The initial studies confirming the IgE-dependence of the late cutaneous allergic response (30) and the LAR (31) were also performed in Hamilton using polyclonal antihuman $\mathrm{IgE}$, which degranulates mast cells and mimics IgE-mediated allergic disease.

\section{AHR as a determinant of airway response to allergen}

Lack of (good) correlation between cutaneous sensitivity to allergen and airway sensitivity to allergen suggested that an additional factor was involved with the shock organ, in this case, the lung (32). Tiffeneau and Pinelli (33) in France and Zuidema (34) in the Netherlands suggested that this factor may well be the degree of AHR to histamine or methacholine and that, with knowledge of the degree of allergy and the level of AHR, it should be possible to predict airway response to allergen. Zuidema (34) produced some preliminary results with house dust mite challenges to support this hypothesis. Killian et al (35) in 1976 were the first to provide objective documentation of the importance of AHR in determining the EAR to allergen. This was supported by a larger study by Cockcroft et al (36), presented in a manner that was conceptually easier for audiences to comprehend. Indeed, the authors found that this relationship was useful in that the amount of allergen required to produce an EAR can be predicted with reasonable certainty by the level of allergen-specific $\operatorname{IgE}$ (assessed by skin test end point, for example) and the magnitude of AHR (assessed by histamine or methacholine challenge) (37).

\section{Allergen-induced AHR}

The demonstration of allergen-induced AHR is arguably the most important single step forward in understanding the pathogenesis of asthma. Before its documentation, it appears that AHR, which is a consistent and indeed a defining feature of asthma, had been regarded as a constant rather than a variable feature. Following on the observations of Altounyan (38), who demonstrated seasonal increases in AHR to histamine, Cockcroft et al (39) in 1977 demonstrated that airway responsiveness to both histamine and methacholine increased in some subjects following allergen challenge (39). This increase was occasionally marked and long lasting, and subsequent studies confirmed the relationship with both the allergen-induced LAR (40) and the seasonal-induced increases in AHR (41). This provided the physiological background for the important concept differentiating asthma stimuli into inducers, ie, those which cause asthma, and inciters, ie, those which induce bronchoconstriction and symptoms in subjects who already have asthma (42). These data also led logically to the re-recognition of airway inflammation as a primary factor in the pathogenesis of (allergeninduced) asthma; these data were supported by observations that the LAR correlated with allergen-induced increase in airway eosinophilia both by bronchoalveolar lavage (43) and by sputum analyses (44), and that AHR itself correlated positively with bronchoalveolar lavage eosinophils and metachromatic cells, a feature identified for the first time in Hamilton (45). Allergen-induced AHR and allergen-induced airway eosinophilia (with or without other markers of airway inflammation) have now become components of most standardized allergen challenge protocols.

\section{Inhaled beta ${ }_{2}$-agonists and airway response to allergen}

While investigating tolerance to the bronchoprotective effect of inhaled beta ${ }_{2}$-agonists, Cockcroft et al (46) made the unexpected but important observation that the regular

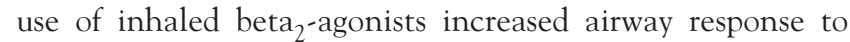
allergen significantly and consistently. Follow-up studies in both Saskatoon, Saskatchewan, and Hamilton documented that this extended to all areas of the allergen-induced response, including the EAR $(46,47)$, the $\operatorname{LAR}(48,49)$ and the allergen-induced airway inflammation (49), probably as a result of regularly inhaled beta ${ }_{2}$-agonists causing mast cell 
dysfunction and increased mediator release (50). These important data provide a plausible mechanism behind the observations that regularly inhaled beta-agonists result in worsened asthma control (51).

\section{Mechanisms of allergen-induced airway responses}

Allergen inhalation challenge has been a useful clinical model to study the mechanisms of allergen-induced airway responses and airway inflammation. The fact that sensitized individuals challenged with inhaled allergens can develop either isolated early responses or dual responses allowed the evaluation of the importance (previously assumed) of progressively worsening airway inflammation in causing the LAR. These studies were greatly helped by the development of methodology for sputum induction and characterization of sputum inflammatory cells, also in Hamilton (52,53), which allowed for a noninvasive method of following the appearance of inflammatory cells into the airway lumen. Studies (54) conducted in Hamilton demonstrated that while individuals with isolated EARs developed an eosinophilic and basophilic airway inflammatory response, this was much greater in those with LARs. Also, the maximum influx of basophils was earlier ( $7 \mathrm{~h}$ after challenge) than for eosinophils ( $24 \mathrm{~h}$ after challenge) (55). Subsequently, studies of allergen-induced eosinophilopoiesis in bone marrow demonstrated that allergen inhalation caused the upregulation of the interleukin (IL) -5 receptor on bone marrow eosinophil progenitors (56), which was caused by cysteinyl leukotriene release following allergen inhalation (57), and increased production of IL-5 in the bone marrow (58), resulting in increased production of eosinophils (59).

Studies (60) examining the mechanisms by which allergeninduced airway inflammation is attenuated in isolated early responders suggested that contrasting profiles of the antiinflammatory cytokines, interferon-gamma and IL-12 released from T-cells may be responsible for different time courses of allergen-induced airway responses between isolated early and dual responders. Finally, the trafficking of antigen presenting cells (dendritic cells) from the blood after allergen inhalation

\section{REFERENCES}

1. Blackley CH. Experimental Researches on the Cause and Nature of Catarrhus Aestivus (Hay-Fever or Hay-Asthma). London: Balliere Tindall \& Cox, 1873.

2. Bostock J. Case of a periodical affection of the eyes and chest. Medico-Chirurgical Transactions 1819;10:161-5.

3. Bostock J. Of the catarrhus aestivus or summer catarrh. Medico-Chirurgical Transactions 1828;XIV:437-46.

4. Emanuel MB. Hay fever, a post industrial revolution epidemic: A history of its growth during the 19th century. Clin Allergy 1988;18:295-304.

5. Stevens FA. A comparison of pulmonary and dermal sensitivity to inhaled substances. J Allergy 1934;5:285-88.

6. Schiller IW, Lowell FC. The effect of drugs in modifying the response of asthmatic subjects to inhalation of pollen extracts as determined by viral capacity measurements. Ann Allergy 1947;5:564-6.

7. Lowell FC, Schiller IW. Measurement of changes in vital capacity as a means of detecting pulmonary reactions to inhaled aerosolized allergenic extracts in asthmatic subjects. J Allergy 1948;19:100-7.

8. Herxheimer H. Induced asthma in man. Lancet 1951;1:1337-41.

9. Herxheimer H. Bronchial obstruction induced by allergens, histamine and acetyl-beta-methylcholinechloride. Int Arch Allergy Appl Immunol 1951;2:27-39.

10. Herxheimer $\mathrm{H}$. Bronchial hypersensitization and hyposensitization in man. Int Arch Allergy Appl Immunol 1951;2:40-59. was studied. The proinflammatory, myeloid dendritic cells decrease in the peripheral blood within $4 \mathrm{~h}$ after allergen inhalation (61) and appear in the airways after $6 \mathrm{~h} \mathrm{(62).} \mathrm{This}$ trafficking is, once again, dependent on cysteinyl leukotriene release after allergen inhalation (63).

\section{Asthma drug evaluation}

The allergen-induced LAR and AHR are considered to be the result of eosinophilic airway inflammation. Drugs that inhibit eosinophilic inflammation are effective asthma medications because they also improve AHR and airflow limitation. Consequently, the allergen challenge model has been useful to explore the efficacy of asthma drugs. Using the standardized reproducible methods outlined above, inhibition of the allergen-induced late sequelae (LAR, AHR and eosinophils) is hypothesized to predict therapeutic value in asthma. Examples include studies showing marked inhibition of the LAR (64-67), AHR (64-67) and eosinophil influx (67) by clinically effective inhaled corticosteroids, while there was no such inhibition when a clinically ineffective inhaled corticosteroid was given (65). Suppression of late sequelae has also been observed with other effective agents, including sodium cromoglycate (64), montelukast sodium (67) and omalizumab (68).

We have successfully pooled our resources with multicentre allergen challenge trials investigating new molecules (69-72), allowing studies to be done in a limited number of subjects in a timely manner. The Canadian Networks of Centres of Excellence, AllerGen NCE Inc, has established a clinical investigator collaborative group (PM O'Byrne and LP Boulet Theme leaders), which has provided a formalized standard multicentre allergen challenge group and has successfully participated in several studies of novel molecules in the past two years. We believe this to be an effective screening test, which may avoid unnecessary large and costly trials.

ACKNOWLEDGEMENTS: The authors wish to thank Jacquie Bramley for assisting in the preparation of this manuscript.

11. Colldahl H. A study of provocation tests on patients with bronchial asthma. I. The reliability of provocation tests performed under different conditions. Acta Allergol 1952;5:133-42.

12. Colldahl H. A study of provocation tests on patients with bronchial asthma. II. The outcome of provocation tests with different antigens. Acta Allergol 1952;5:143-53.

13. Herxheimer $\mathrm{H}$. The late bronchial reaction in induced asthma. Int Arch Allergy Appl Immunol 1952;3:323-8.

14. Schiller IW, Lowell FC. The inhalation test as a diagnostic procedure with special emphasis on the house dust allergen. J Allergy 1952;23:234-41.

15. O'Byrne PM, Dolovich J, Hargreave FE. State of the art: Late asthmatic responses. Am Rev Respir Dis 1987;136:740-51.

16. Tiffeneau R, Pinelli A. Air circulant et air captif dans l'exploration de la fonction ventilatrice pulmonaire. Paris Méd 1947;37:624-8.

17. Gandevia B, Hugh-Jones P. Terminology for measurements of ventilatory capacity; a report to the thoracic society. Thorax 1957;12:290-3.

18. Citron KM, Frankland AW, Sinclair JD. Inhalation tests of bronchial hypersensitivity in pollen asthma. Thorax 1958;13:229-32.

19. Burtin P, Buffe D, Carton J, Dominson-Monnier F, Kourilsky R. L'allergie retardée à la poussière de maison. Int Arch Allergy 1962;21:8-19.

20. Van Lookeren Campagne JG, Knol K, De Vries K. House dust provocation in children. Scand J Respir Dis 1969;50:76-85. 
21. Booij-Noord H, Orie NG, De Vries K. Immediate and late bronchial obstructive reactions to inhalation of house dust and protective effects of disodium cromoglycate and prednisolone. J Allergy Clin Immunol 1971;48:344-54.

22. Booij-Noord H, de Vries K, Sluiter HJ, Orie NG. Late bronchial obstructive reaction to experimental inhalation of house dust extract. Clin Allergy 1972;2:43-61.

23. Orie NGM, Van Lookeren Campagne JG, Knol K, Booij-Noord H, de Vries K. Late reactions in bronchial asthma. In: Pepys J, Yamamura I, eds. Intal in Bronchial Asthma. Tokyo: Proceedings of the 8th International Congress of Allergollogy, 1974:17-29.

24. Pepys J, Chan M, Hargreave FE, McCarthy DS. Inhibitory effects of disodium cromoglycate on allergen-inhalation tests. Lancet $1968 ; 2: 134-7$

25. Pepys J. Immunological mechanisms in asthma. In: Porter R, Birch J, eds. Identification of Asthma. London: Churchill Livingstone, 1971:87-97.

26. Pepys J, Davies RJ, Breslin AB, Hendrick DJ, Hutchcroft BJ. The effects of inhaled beclomethasone dipropionate (Becotide) and sodium cromoglycate on asthmatic reactions to provocation tests. Clin Allergy 1974:4:13-24

27. Pepys J, Hutchcroft BJ. Bronchial provocation tests in etiologic diagnosis and analysis of asthma. Am Rev Respir Dis 1975;112:829-59.

28. Ishizaka K, Ishizaka T. Identification of gamma-E-antibodies as a carrier of reaginic activity. J Immunol 1967;99:1187-98.

29. Robertson DG, Kerigan AT, Hargreave FE, Chalmers R, Dolovich J. Late asthmatic responses induced by ragweed pollen allergen. J Allergy Clin Immunol 1974;54:244-54.

30. Dolovich J, Hargreave FE, Chalmers R, Shier KJ, Gauldie J, Bienenstock J. Late cutaneous allergic responses in isolated IgE-dependent reactions. J Allergy Clin Immunol 1973;52:38-46.

31. Kirby JG, Robertson DG, Hargreave FE, Dolovich J. Asthmatic responses to inhalation of anti-human IgE. Clin Allergy 1986;16:191-4.

32. Feinberg SM, Stier RA, Grater WC. A suggested quantitative evaluation of the degree of sensitivity of patients with ragweed pollinosis. J Allergy 1952;23:387-94.

33. Tiffeneau R, Pinelli A. Air circulant et air captif dans l'exploration de la fonction ventilatrice pulmonaire. Paris Méd 1947;37:624-8

34. Zuidema P. Value of inhalation tests in bronchial asthma. Respiration 1969;26(Suppl):141-50.

35. Killian D, Cockcroft DW, Hargreave FE, Dolovich J. Factors in allergen-induced asthma: Relevance of the intensity of the airways allergic reaction and non-specific bronchial reactivity. Clin Allergy 1976;6:219-25.

36. Cockcroft DW, Ruffin RE, Frith PA, et al. Determinants of allergen-induced asthma: Dose of allergen, circulating IgE antibody concentration and bronchial responsiveness to inhaled histamine. Am Rev Respir Dis 1979;120:1053-8.

37. Cockcroft DW, Murdock KY, Kirby J, Hargreave FE. Prediction of airway responsiveness to allergen from skin sensitivity to allergen and airway responsiveness to histamine. Am Rev Respir Dis 1987;135:264-7.

38. Altounyan REC. Changes in histamine and atropine responsiveness as a guide to diagnosis and evaluation of therapy in obstructive airways disease. In: Pepys J, Franklands AW, eds. Disodium Cromoglycate in Allergic Airways Disease. London: Butterworth, 1970:47-53.

39. Cockcroft DW, Ruffin RE, Dolovich J, Hargreave FE. Allergen-induced increase in non-allergic bronchial reactivity. Clin Allergy 1977;7:503-13.

40. Cartier A, Thomson NC, Frith PA, Roberts R, Hargreave FE. Allergen-induced increase in bronchial responsiveness to histamine: Relationship to the late asthmatic response and change in airway caliber. J Allergy Clin Immunol 1982;70:170-7.

41. Boulet LP, Cartier A, Thomson NC, Roberts RS, Dolovich J, Hargreave FE. Asthma and increases in nonallergic bronchial responsiveness from seasonal pollen exposure. J Allergy Clin Immunol 1983;71:399-406.

42. Dolovich J, Hargreave FE. The asthma syndrome: Inciters, inducers, and host characteristics. Thorax 1981;36:641-4

43. De Monchy JG, Kauffman HF, Venge P, et al. Bronchoalveolar eosinophilia during allergen-induced late asthmatic reactions. Am Rev Respir Dis 1985;131:373-6.
44. Pin I, Freitag AP, O'Byrne PM, et al. Changes in the cellular profile of induced sputum after allergen-induced asthmatic responses. Am Rev Respir Dis 1992;145:1265-9.

45. Kirby JG, Hargreave FE, Gleich GJ, O’Byrne PM. Bronchoalveolar cell profiles of asthmatic and nonasthmatic subjects. Am Rev Respir Dis 1987;136:379-83.

46. Cockcroft DW, McParland CP, Britto SA, Swystun VA, Rutherford BC. Regular inhaled salbutamol and airway responsiveness to allergen. Lancet 1993;342:833-37.

47. Cockcroft DW, Swystun VA, Bhagat R. Interaction of inhaled beta 2 agonist and inhaled corticosteroid on airway responsiveness to allergen and methacholine. Am J Respir Crit Care Med 1995;152:1485-9.

48. Cockcroft DW, O'Byrne PM, Swystun VA, Bhagat R. Regular use of inhaled albuterol and the allergen-induced late asthmatic response. J Allergy Clin Immunol 1995;96:44-9.

49. Gauvreau GM, Jordana M, Watson RM, Cockcroft DW, O'Byrne PM. Effect of regular inhaled albuterol on allergen-induced late responses and sputum eosinophils in asthmatic subjects. Am J Respir Crit Care Med 1997;156:1738-45.

50. Swystun VA, Gordon JR, Davis EB, Zhang X, Cockcroft DW. Mast cell tryptase release and asthmatic responses to allergen increase with regular use of salbutamol. J Allergy Clin Immunol 2000;106:57-64.

51. Sears MR, Taylor DR, Print CG, et al. Regular inhaled beta-agonist treatment in bronchial asthma. Lancet 1990;336:1391-6.

52. Pin I, Gibson PG, Kolendowicz R, et al. Use of induced sputum cell counts to investigate airway inflammation in asthma. Thorax 1992:47:25-9.

53. Pizzichini E, Pizzichini MM, Efthimiadis A, et al. Indices of airway inflammation in induced sputum: Reproducibility and validity of cell and fluid-phase measurements. Am J Respir Crit Care Med 1996;154:308-17.

54. Gauvreau GM, Watson RM, O'Byrne PM. Kinetics of allergen-induced airway eosinophilic cytokine production and airway inflammation. Am J Respir Crit Care Med 1999;160:640-7.

55. Gauvreau GM, Lee JM, Watson RM, Irani AM, Schwartz LB, O'Byrne PM. Increased numbers of both airway basophils and mast cells in sputum after allergen inhalation challenge of atopic asthmatics. Am J Respir Crit Care Med 2000;161:1473-8.

56. Sehmi R, Wood LJ, Watson R, et al. Allergen-induced increases in IL-5 receptor alpha-subunit expression on bone marrow-derived CD34+ cells from asthmatic subjects. A novel marker of progenitor cell commitment towards eosinophilic differentiation. J Clin Invest 1997;100:2466-75

57. Parameswaran K, Watson R, Gauvreau GM, Sehmi R, O’Byrne PM. The effect of pranlukast on allergen-induced bone marrow eosinophilopoiesis in subjects with asthma. Am J Respir Crit Care Med 2004;169:915-20.

58. Wood LJ, Inman MD, Watson RM, Foley R, Denburg JA, O'Byrne PM. Changes in bone marrow inflammatory cell progenitors after inhaled allergen in asthmatic subjects. Am J Respir Crit Care Med 1998;157:99-105.

59. Dorman SC, Sehmi R, Gauvreau GM, et al. Kinetics of bone marrow eosinophilopoiesis and associated cytokines after allergen inhalation. Am J Respir Crit Care Med 2004;169:565-72.

60. Yoshida M, Watson RM, Rerecich T, O'Byrne PM. Different profiles of T-cell IFN-gamma and IL-12 in allergen-induced early and dual responders with asthma. J Allergy Clin Immunol 2005:115:1004-9.

61. Upham JW, Denburg JA, O'Byrne PM. Rapid response of circulating myeloid dendritic cells to inhaled allergen in asthmatic subjects. Clin Exp Allergy 2002;32:818-23.

62. Jahnsen FL, Moloney ED, Hogan T, Upham JW, Burke CM, Holt PG. Rapid dendritic cell recruitment to the bronchial mucosa of patients with atopic asthma in response to local allergen challenge. Thorax 2001;56:823-6.

63. Parameswaran K, Liang H, Fanat A, Watson R, Snider DP, O'Byrne PM. Role for cysteinyl leukotrienes in allergen-induced change in circulating dendritic cell number in asthma. J Allergy Clin Immunol 2004;114:73-9.

64. Cockcroft DW, Murdock KY. Comparative effects of inhaled salbutamol, sodium cromoglycate, and beclomethasone dipropionate on allergen-induced early asthmatic responses, late asthmatic responses, and increased bronchial responsiveness to histamine. J Allergy Clin Immunol 1987;79:734-40. 
65. Kidney JC, Boulet LP, Hargreave FE, et al. Evaluation of single-dose inhaled corticosteroid activity with an allergen challenge model. J Allergy Clin Immunol 1997;100:65-70.

66. Inman MD, Watson RM, Rerecich T, et al. Dose-dependent effects of inhaled mometasone furoate on airway function and inflammation after allergen inhalation challenge. Am J Respir Crit Care Med 2001;164:569-74.

67. Leigh R, Vethanayagam D, Yoshida M, et al. Efects of montelukast and budesonide on airway responses and airway inflammation in asthma. Am J Respir Crit Care Med 2002;166:1212-7.

68. Fahy JV, Fleming HE, Wong HH, et al. The effect of an anti-IgE monoclonal antibody on the early- and late-phase responses to allergen inhalation in asthmatic subjects. Am J Respir Crit Care Med 1997;155:1828-34.
69. Boulet LP, Chapman KR, Côté J, et al. Inhibitory effects of an anti-IgE antibody E25 on allergen-induced early asthmatic response. Am J Respir Crit Care Med 1997;155:1835-40.

70. Gauvreau GM, Becker AB, Boulet LP, et al. The effects of an anti-CD11a mAb, efalizumab, on allergen-induced airway responses and airway inflammation in subjects with atopic asthma. J Allergy Clin Immunol 2003;112:331-8.

71. Gauvreau GM, Boulet LP, Postma DS, et al. Effect of low-dose ciclesonide on allergen-induced responses in subjects with mild allergic asthma. J Allergy Clin Immunol 2005;116:285-91.

72. Gauvreau GM, Hessel EM, Boulet LP, Coffman RL, O'Byrne PM. Immunostimulatory sequences regulate interferon-inducible genes but not allergic airway responses. Am J Respir Crit Care Med 2006;174:15-20. 


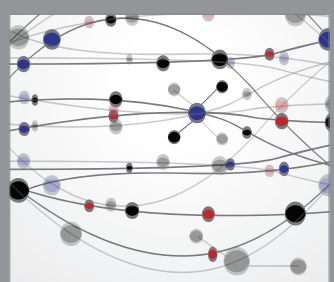

The Scientific World Journal
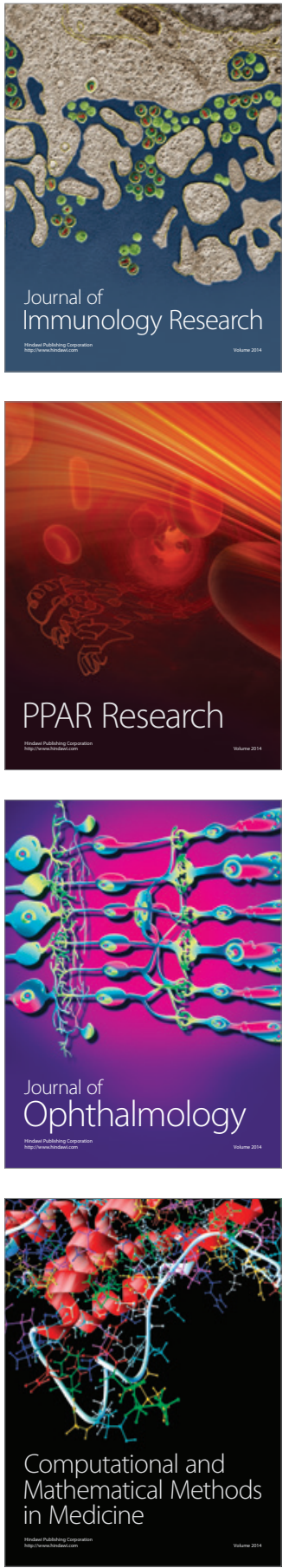

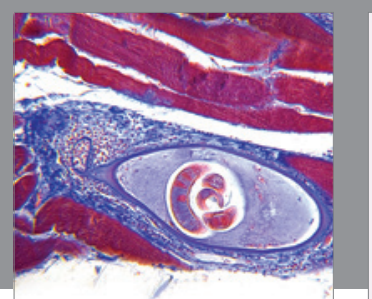

Gastroenterology Research and Practice

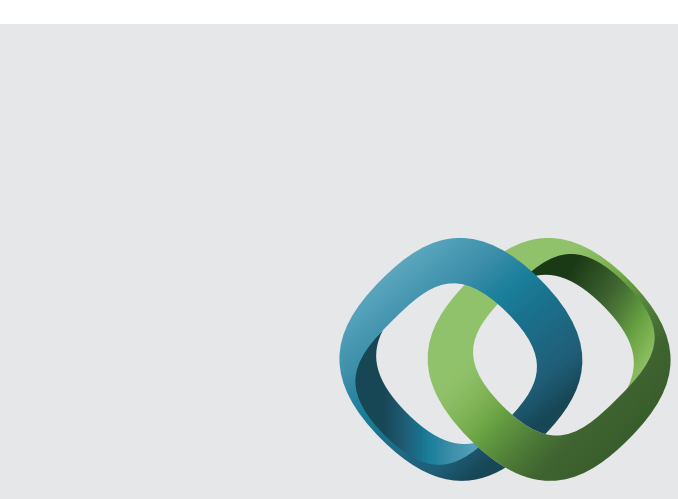

\section{Hindawi}

Submit your manuscripts at

http://www.hindawi.com
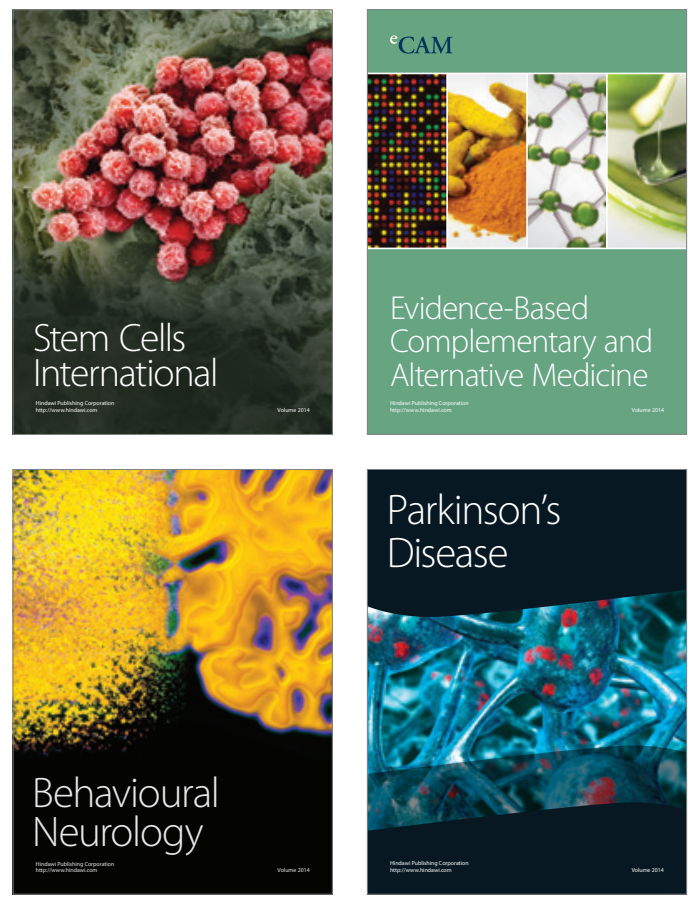
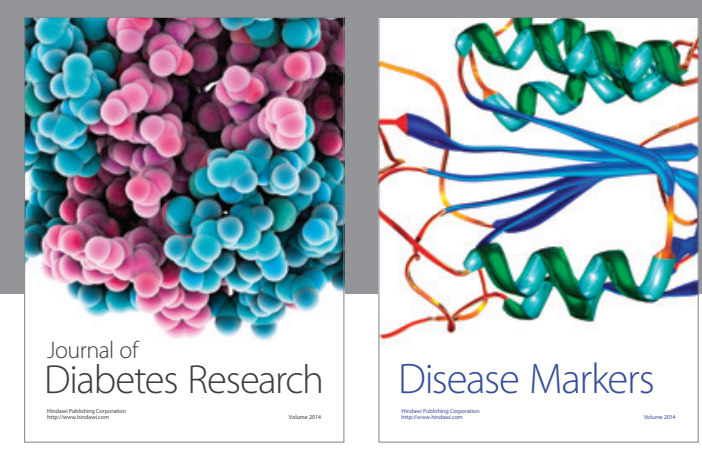

Disease Markers
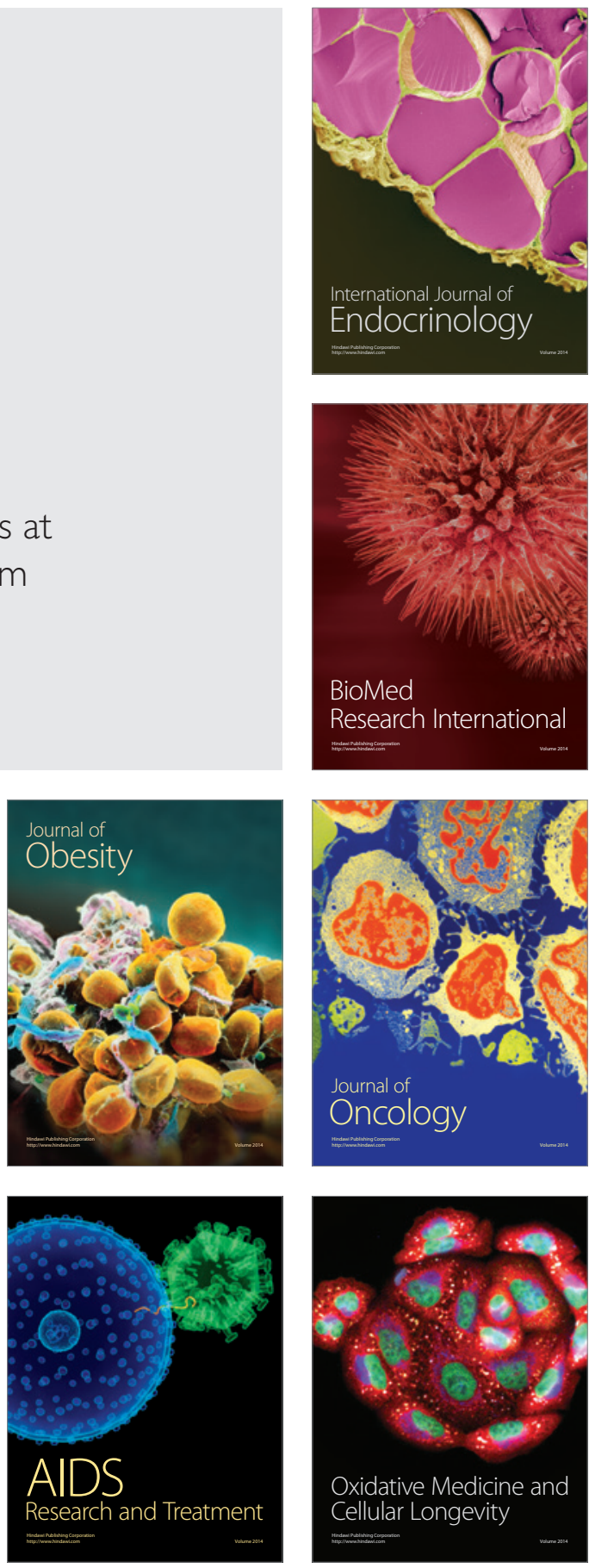